\title{
Nutritive value of navy beans (Phaseolus vulgaris)*
}

\author{
By M. L. KAKADE AND R. J. EVANS \\ Department of Biochemistry, Michigan State University, \\ East Lansing, Michigan, USA \\ (Received 6 October 1964-Accepted 18 Fanuary 1965)
}

It has been known since I 920 (Johns \& Finks, r920) that the navy bean is an inferior source of protein for rats. Everson \& Heckert (1944) reported that raw navy beans were injurious to rats when given at a $10 \%$ protein level. They also reported that autoclaving the beans destroyed the injurious effect. Kakade \& Evans $\left(\mathrm{Ig}_{3} a, b\right)$ confirmed this report and observed that rats given $10 \%$ protein as raw navy beans in an otherwise nutritionally complete diet lost weight and died during the experiment.

The beneficial and adverse effects of heat on legume proteins have been reviewed by Liener (1958). The beneficial effect of heat on most legumes has been generally attributed to the destruction of antinutritional factors such as trypsin inhibitor and haemagglutinin present in them. Bowman (I944) and Rigas \& Osgood (I955) have shown the presence of a partially heat-labile trypsin inhibitor and a haemagglutinin respectively in navy beans. One purpose of the experiment now described was to determine by indirect means the importance of these 'toxic' factors in the low nutritive value of navy beans.

Recently, Bandemer \& Evans (1963) compared the amino acid composition of navy beans with that of a provisional amino acid pattern (FAO, I957) and reported that the sulphur-containing amino acids are the most limiting amino acids of navy beans. A study was therefore conducted to see if the observed growth inhibition of rats fed on navy beans is a result of amino acid deficiency or of amino acid imbalance.

\section{EXPERIMENTAL}

\section{Preparation of beans}

Navy beans of the Sanilac variety (courtesy of Dr M. Wayne Adams, Farm Crops Department, Michigan State University) were ground into fine flour. The beans contained $24.00 \%$ crude protein $(\mathrm{N} \times 6.25)$ determined by the Kjeldahl-WilfarthGunning method (Association of Official Agricultural Chemists, r950). Heated samples were prepared by autoclaving the finely ground beans in shallow pans at a thickness not exceeding $\mathrm{I} \cdot \mathrm{O} \mathrm{cm}$ at $\mathrm{I} 2 \mathrm{I}^{\circ}$ for $5, \mathrm{I} 5,30,60$ or $240 \mathrm{~min}$, after the desired temperature had been reached. After autoclaving, the samples were placed before a fan and allowed to dry at room temperature.

\footnotetext{
* Journal article no. 3226 from the Michigan Agricultural Experiment Station. Supported in part by a grant from the Michigan Bean Shippers Association.
} 


\section{Preparation of diet}

The percentage composition of the basal diet was: sucrose 30, maize oil 6, Hegsted salt mixture (Hegsted, Mills, Elvehjem \& Hart, I94I) (purchased from Nutritional Biochemicals Corporation, Cleveland, Ohio) 4, vitamin diet fortification mixture (purchased from Nutritional Biochemicals Corporation, Cleveland, Ohio) 2. The vitamin mixture supplied $(\mathrm{mg} / \mathrm{I} 00 \mathrm{~g}$ diet): vitamin A concentrate (200000 i.u./g) $9^{\circ} \circ$, vitamin D concentrate (400000 i.u. $/ g$ ) $5^{\circ} \circ$, tocopherol $10 \cdot 0$, ascorbic acid $9^{\circ} \circ$, inositol 10.0 , choline chloride 150.0 , menaphthone $4.5, p$-aminobenzoic acid 10.0 , nicotinic acid $9 \cdot 0$, riboflavine $2 \cdot 0$, pyridoxine hydrochloride $2 \cdot 0$, thiamine hydrochloride $2 \cdot 0$, calcium pantothenate 6.0 , biotin 0.04 , folic acid 0.18 , vitamin $B_{12} 0.0027$. Raw or autoclaved navy beans or vitamin-free casein was incorporated into the basal diet to provide $10 \%$ protein $(\mathrm{N} \times 6 \cdot 25)$. Maize starch was added to make the total to 100 .

\section{Procedure}

Protein quality was evaluated with weanling albino rats, $2 \mathrm{I}-24$ days old. The rats were divided into groups of six animals, each housed in an individual wire-bottom cage and the groups were equalized as nearly as possible with respect to sex and weight. Food and water were supplied $a d$ lib. Rats were weighed weekly and accurate records were kept of food consumption over the 4-week experimental period. Protein efficiency ratio (PER) was calculated as change in body-weight in $\mathrm{g} / \mathrm{g}$ protein consumed.

Trypsin inhibitor activity was determined by the casein digestion method of Kunitz (1946-7a) and haemagglutinating activity by the method of Liener (1953).

\section{RESULTS AND DISCUSSION}

The effect of various heating periods on the nutritive value of navy beans as measured by rat growth is given in Table $\mathrm{I}$. Rats fed on raw navy beans as a source of protein lost weight and died within $20-26$ days. On the other hand, rats fed on navy beans autoclaved for $5 \mathrm{~min}$ gained weight, and there was a considerable increase in total food intake over that of rats fed on raw beans. However, the lower PER values for rats fed on beans autoclaved for longer than 5 min indicate the adverse effect of heat treatment on the nutritive value of navy beans. It is likely that these PER values may have been caused by the destruction or inactivation of essential amino acids in the manner described by Evans \& Butts (1949).

The effect of heat treatment on trypsin inhibitor and haemagglutinin activities was investigated (Table 2) because these have been suggested as the growth-inhibiting materials in navy beans (Liener, 1958). Autoclaving of raw beans for 5 min destroyed $80 \%$ of the trypsin inhibitor activity and $100 \%$ of the haemagglutinin activity. Thus, the low nutritive value of raw navy beans may be due to the presence of heat-labile trypsin inhibitor and haemagglutinin. Honavar, Shih \& Liener (1962) reported growth inhibition of rats fed on purified haemagglutinin isolated from beans (Phaseolus vulgaris).

Borchers $\left(195^{8}\right)$ gave various dietary levels of raw soya-bean meal to weanling rats 
Table 1 . Effect of raw and heated navy beans on the growth of rats

(Mean values for groups of six rats given the experimental diets for 4 weeks)

\begin{tabular}{|c|c|c|c|}
\hline Protein source & $\begin{array}{c}\text { Weight } \\
\text { change } \\
\text { (g) }\end{array}$ & $\begin{array}{c}\text { Food } \\
\text { intake } \\
(\mathrm{g})\end{array}$ & $\begin{array}{c}\text { Protein } \\
\text { efficiency ratio } \\
\text { (g gain in body- } \\
\text { weight } / g \text { proteir } \\
\text { consumed) }\end{array}$ \\
\hline & $98 \cdot 0$ & 286 & $3 \cdot 4 \mathrm{I}$ \\
\hline $\mathrm{v}$ beans & $-13 \cdot 2$ & 92 & All died \\
\hline as autoclaved for $5 \mathrm{~min}$ & $35^{\circ} \circ$ & 226 & $\mathbf{1} \cdot 57$ \\
\hline is autoclaved for $15 \mathrm{~min}$ & $25 \cdot 0$ & I97 & $1 \cdot 26$ \\
\hline autoclaved for $30 \mathrm{~min}$ & $21 \cdot 0$ & 198 & I.09 \\
\hline autoclaved for I h & $12 \cdot 0$ & 167 & 0.67 \\
\hline ans autoclaved for $4 \mathrm{~h}$ & $-8 \cdot 0$ & 164 & 0 \\
\hline
\end{tabular}

Table 2. Effect of heat on haemagglutinating and trypsin inhibitor activities of crude extracts of navy beans

$\begin{array}{lcc}\text { Haemagglutinating } & \begin{array}{c}\text { Trypsin } \\ \text { activity } \\ \left(\mathrm{HU}^{*} / \mathrm{ml}\right)\end{array} & \begin{array}{c}\text { inhibitor activity } \\ \left.\text { (TIUt/ml } \times 10^{3}\right)\end{array} \\ \text { Heat treatment } & 5 \mathrm{r} & 2250 \\ 5 \mathrm{~min}, 121^{\circ} & 0 & 400 \\ 15 \mathrm{~min}, 121^{\circ} & 0 & 260 \\ 30 \mathrm{~min}, 121^{\circ} & 0 & 260 \\ 60 \mathrm{~min}, 121^{\circ} & 0 & 0 \\ 240 \mathrm{~min}, 121^{\circ} & 0 & 0\end{array}$

* Haemagglutinin unit defined as the least amount of haemagglutinin that will produce positive evidence of agglutination $(\mathrm{I}+)$ of $0.2 \mathrm{ml}$ of $4 \%$ suspension of washed chicken red blood cells after $\mathrm{I} h$ incubation at $37^{\circ}$.

+ Trypsin inhibitor unit expressed in terms of tryptic units inhibited, the tryptic unit being defined as the increase of one unit of extinction at $280 \mathrm{~nm} / \mathrm{min}$ of digestion under the experimental conditions.

\section{Table 3. Effect of various dietary levels of casein and raw navy beans on the growth of rats}

(Mean values for groups of six rats given the experimental diets for 4 weeks)

\begin{tabular}{|c|c|c|}
\hline \multicolumn{2}{|c|}{ Protein in diet $(\%)$} & \multirow{2}{*}{$\begin{array}{c}\text { Weight } \\
\text { change } \\
\text { (g) }\end{array}$} \\
\hline Casein & Raw beans & \\
\hline $10 \cdot 0$ & 0.0 & $82 \cdot 0$ \\
\hline $7 \cdot 5$ & $2 \cdot 5$ & $44^{\circ}$ \\
\hline $5 \cdot 0$ & $5 \cdot 0$ & $2 \cdot 0$ \\
\hline $2 \cdot 5$ & $7 \cdot 5$ & $-8 \cdot 0$ \\
\hline 0.0 & 10.0 & $-12 \cdot 3$ \\
\hline 0.0 & 20.0 & \\
\hline
\end{tabular}

Protein efficiency ratio ( $g$ gain in bodyweight/g protein consumed)

All died in 5-10 days

$2 \cdot 67$
$1 \cdot 89$
$\circ .16$
$\circ$
All died

to see if there is a 'toxic' factor in raw soya beans. Table 3 shows the effect on the growth of rats of substituting raw navy beans for casein at various levels in a $10 \%$ protein diet. The weight gain and total food intake decreased as the level of beans in the diet increased. Rats fed on raw navy beans at a $20 \%$ protein level died within 
5-10 days from the beginning of the experiment, which is quite consistent with the hypothesis that the effect of a toxic factor would be enhanced at a higher level of intake. Navy beans thus appear to contain a 'toxic' factor(s).

Table 4 shows the effect on rat growth of replacing casein with autoclaved beans. PER values obtained with diets containing beans at $2.5,5.0$ or $7.5 \%$ protein level were progressively lower than PER values obtained with the casein diet, and the PER value obtained with $10 \%$ bean protein was very much less than that with casein. This observation may have some practical implications in certain countries where there is

Table 4. Effect of various dietary levels of casein and of navy beans autoclaved at $\mathrm{I}_{2} \mathrm{I}^{\circ}$ for 5 min on the growth of rats

(Mean values for groups of six rats given the experimental diets for 4 weeks)

$\overbrace{\text { Casein }}^{\text {Protein in diet }(\%)}$

$\begin{array}{ccc}\begin{array}{c}\text { Weight } \\ \text { change } \\ (\mathrm{g})\end{array} & \begin{array}{c}\text { Food } \\ \text { intake } \\ (\mathrm{g})\end{array} & \begin{array}{c}\text { Protein } \\ \text { efficiency ratio } \\ \text { (g gain in body- } \\ \text { weight/g protein } \\ \text { consumed) }\end{array} \\ 85.0 & & \\ 81.0 & 305 & 2 \cdot 85 \\ 75.0 & 289 & 2 \cdot 81 \\ 64.0 & 280 & 2 \cdot 67 \\ 47.0 & 266 & 2 \cdot 37 \\ 90.0 & 255 & 1 \cdot 84 \\ & 260 & 1 \cdot 62\end{array}$

Table 5. Essential amino acid composition of casein, of raw and autoclaved navy beans, of the FAO (1957) reference pattern, and of the pattern proposed by Rose (1937) for growing rats, expressed as $g$ amino acid/100 $g$ protein

\begin{tabular}{|c|c|c|c|c|c|}
\hline Amino acid & Casein * & $\begin{array}{c}\text { Raw } \\
\text { beanst }\end{array}$ & $\begin{array}{c}\text { Autoclaved } \\
\text { beanst }\end{array}$ & $\begin{array}{c}\text { FAO } \\
\text { pattern }\end{array}$ & $\begin{array}{c}\text { Rose } \\
\text { pattern }\end{array}$ \\
\hline Arginine & $4 \cdot 3$ & $5 \cdot 6$ & $5 \cdot 5$ & - & $2 \cdot 0$ \\
\hline Histidine & $3 \cdot 1$ & $2 \cdot 6$ & $2 \cdot 8$ & - & $4 \cdot 0$ \\
\hline Isoleucine & $6 \cdot 5$ & $4 \cdot 6$ & $5 \cdot 4$ & $4 \cdot 2$ & 50 \\
\hline Leucine & 9.7 & $7 \cdot 5$ & $8 \cdot 4$ & $4 \cdot 8$ & $8 \cdot 0$ \\
\hline Lysine & $8 \cdot 7$ & $7 \cdot 1$ & $7 \cdot 2$ & $4 \cdot 2$ & $10 \cdot 0$ \\
\hline Methionine & 3.0 & $1 \cdot 0$ & I.O & $4 \cdot 2 t$ & $4 \cdot 0$ \\
\hline Phenylalanine & $5 \cdot 8$ & $5 \cdot 1$ & $5 \cdot 0$ & $2 \cdot 8$ & $7 \cdot 0$ \\
\hline Threonine & 47 & $4 \cdot 6$ & $5 \cdot 3$ & $2 \cdot 6$ & $5 \cdot 0$ \\
\hline Tryptophan & $x \cdot 5$ & I. 4 & I. 8 & I 4 & $2 \cdot 0$ \\
\hline Valine & $7 \cdot 4$ & 4.8 & $5 \cdot 6$ & $4 \cdot 2$ & $7 \cdot 0$ \\
\hline
\end{tabular}

a shortage of animal protein food. Rats fed on autoclaved beans at a $20 \%$ protein level grew as well as those fed on casein at $10 \%$ protein. Our unpublished findings indicate that when the bean protein level was increased from to to $20 \%$ the methionine-cystine content of the ration was increased from 0.2 to $0.40 \%$ compared to $0.38 \%$ in the $10 \%$ casein diet. Cystine and methionine were determined by ion exchange chromatography (Bandemer \& Evans, 1963).

The poor growth of rats fed on beans at a 10\% protein level must thus have been 
due to a deficiency of sulphur-containing amino acids rather than to amino acid imbalance. It was shown in a previous paper (Kakade $\&$ Evans, 1964) that rats fed on an autoclaved bean diet supplemented with methionine grew as well as those fed on the casein diet.

Table 6. Growth of rats fed on diets containing navy beans, raw or autoclaved at $12 \mathrm{I}^{\circ}$ for $5 \mathrm{~min}$, supplemented with essential amino acids

(Mean values for groups of six rats given the experimental diets for 4 weeks)

\begin{tabular}{|c|c|c|c|c|}
\hline $\begin{array}{c}\text { Group } \\
\text { no. }\end{array}$ & Protein source & $\begin{array}{l}\text { Weight } \\
\text { change } \\
\text { (g) }\end{array}$ & $\begin{array}{l}\text { Food } \\
\text { intake } \\
(\mathrm{g})\end{array}$ & $\begin{array}{c}\text { Protein } \\
\text { efficiency ratio } \\
\text { (g gain in body- } \\
\text { weight } / \mathrm{g} \text { protein } \\
\text { consumed) }\end{array}$ \\
\hline $\mathbf{I}$ & Casein & 106.0 & 352 & $3 \cdot 18$ \\
\hline 2 & Raw beans & $-14 \cdot 6$ & 96 & All died \\
\hline 3 & Autoclaved beans & $42 \cdot 0$ & 221 & $\mathbf{I} \cdot 90$ \\
\hline 4 & Raw beans + methionine* & -15.0 & 102 & All died \\
\hline 5 & $\begin{array}{l}\text { Autoclaved beans }+ \\
\text { methionine* }\end{array}$ & $94^{\circ} \circ$ & 300 & $3 \cdot 13$ \\
\hline 6 & Raw beans + amino acids $\dagger$ & $-16 \cdot 0$ & 103 & 0 \\
\hline 7 & $\begin{array}{l}\text { Autoclaved beans + amino } \\
\text { acids } \dagger\end{array}$ & $102 \cdot 0$ & 320 & $3 \cdot 19$ \\
\hline 8 & Raw beans + amino acids $\ddagger$ & $-16 \cdot 3$ & II0 & 0 \\
\hline \multirow[t]{2}{*}{9} & $\begin{array}{l}\text { Autoclaved beans }+ \text { amino } \\
\text { acids } \downarrow\end{array}$ & $100 \cdot 0$ & 312 & $3 \cdot 20$ \\
\hline & $\begin{array}{l}\text { Methionine added to bring } \\
\text { Amino acids added to brin } \\
\text { Amino acids added to brin }\end{array}$ & $\begin{array}{l}\text { ecomme } \\
\text { propose } \\
\text { furnishe }\end{array}$ & $\begin{array}{l}\text { FAO } \\
\text { e (193 } \\
\text { in. }\end{array}$ & \\
\hline
\end{tabular}

\section{Table 7. Effect of supplementary trypsin* on the growth of rats given navy beans or navy beans autoclaved at $12 \mathrm{1}^{\circ}$ for $5 \mathrm{~min}$}

(Mean values for groups of six rats given the experimental diets for 4 weeks)

\begin{tabular}{|c|c|c|c|c|}
\hline $\begin{array}{c}\text { Expt } \\
\text { no. }\end{array}$ & Protein source & $\begin{array}{c}\text { Weight } \\
\text { change } \\
\text { (g) }\end{array}$ & $\begin{array}{l}\text { Food } \\
\text { intake } \\
\text { (g) }\end{array}$ & $\begin{array}{c}\text { Protein } \\
\text { efficiency ratio } \\
\text { ( } \mathrm{g} \text { gain in body- } \\
\text { weight } / \mathrm{g} \text { protein } \\
\text { consumed) }\end{array}$ \\
\hline $\mathbf{I}$ & Raw beans & $-12 \cdot 8$ & 88 & All died \\
\hline 2 & Raw beans $+\mathrm{r} \%$ trypsin & $-\mathrm{II} \cdot 4$ & 80 & All died \\
\hline 3 & Raw beans $+2 \%$ trypsin & $-Y I \cdot 0$ & 82 & All died \\
\hline 4 & Raw beans $+3 \%$ trypsin & -10.8 & 76 & All died \\
\hline 5 & Autoclaved beans & $32 \cdot 0$ & 210 & $I \cdot 58$ \\
\hline 6 & Autoclaved beans + I \% trypsin & $25 \cdot 0$ & 190 & $I \cdot 3 I$ \\
\hline 7 & Autoclaved beans $+2 \%$ trypsin & $16 \cdot 0$ & 148 & 3 died \\
\hline 8 & Autoclaved beans $+3 \%$ trypsin & $-7 \cdot 2$ & 84 & All died \\
\hline
\end{tabular}

* Trypsin $\left(1: 3^{\circ 0}\right)$ purchased from Nutritional Biochemicals Corporation, Cleveland, Ohio.

Comparison of the amino acid composition of raw or autoclaved navy beans with that of the FAO reference pattern (FAO, 1957) shows bean protein to be deficient primarily in methionine. However, as indicated in Table 5 , a comparison with the essential amino acid pattern proposed by Rose (1937) for growing rats and with the amino acid composition of casein shows that navy beans might be deficient in most 
essential amino acids. The results obtained by supplementing navy beans with amino acids are presented in Table 6 . Supplementation of the raw bean diet with methionine or with all amino acids in which the diet might have been deficient did not overcome the growth depression although mortality was reduced. However, rats fed on the autoclaved bean diet supplemented with methionine alone (group 5) or with all amino acids in question grew as well as rats fed on the casein diet. There appears to be no advantage in adding any amino acid other than methionine to the autoclaved bean diet. The results indicate that the FAO reference pattern provides sufficient amino acids for growth of rats. They also indicate that the growth inhibition of rats fed on raw navy beans does not arise from an amino acid imbalance.

\section{Table 8. Effect of soaked* navy beans on the growth of rats}

(Mean values for groups of six rats given the experimental diets for 4 weeks)

With raw soya beans the beneficial effect of supplementary trypsin on the growth of rats (Borchers \& Ackerson, I95I) and chicks (Almquist \& Merritt, 1953) can be attributed to trypsin-trypsin-inhibitor complex formation (Kunitz, 1946-7b) neutralizing the antitryptic activity of the beans. An experiment was therefore conducted to determine whether trypsin supplementation of navy bean diets would improve their nutritive value for rats. The results obtained are presented in Table 7 and indicate that trypsin supplementation did not overcome the growth depression of rats fed on raw navy beans. Moreover, it was observed that trypsin supplementation was detrimental to rats receiving an autoclaved bean diet. These observations are consistent with those of Brambila, Nesheim \& Hill (196r) who reported the detrimental effects of trypsin supplementation on the growth of chicks receiving either raw or heated soyabean meal.

It has been reported (Honavar et al. 1962; Jaffé, 1949) that soaking beans (Phaseolus vulgaris) before heat treatment is essential for normal growth of rats fed on them. The values in Table 8, however, show that soaking the beans did not improve their growth-promoting effects. This was true when raw or autoclaved navy beans were 
used and when methionine was added to the diet. The importance of haemagglutinin as a causative factor in the toxicity of the variety of beans belonging to $P$. vulgaris has been reviewed by Liener (1962). He stated that 'if a haemagglutinin is responsible for the toxicity of raw kidney beans', as postulated by Honavar et al. (1962), 'then it must follow that the haemagglutinin can only be destroyed in the raw meal by preliminary soaking followed by autoclaving'. The results presented in Table 8 are in contrast to studies of Honavar et al. (1962) and Jaffé (1949). The reason for these different results may possibly be the use of different varieties of the beans belonging to the species P. vulgaris.

\section{SUMMARY}

I. Navy beans (Phaseolus vulgaris) were finely ground and heated in the autoclave at $\mathrm{I} 2 \mathrm{I}^{\circ}$ for various lengths of time. The bean flours were offered to rats and analysed for haemagglutinating and trypsin inhibitor activities. Effect on rat growth of progressive replacement of casein with raw or autoclaved $(5 \mathrm{~min})$ bean proteins, of supplementation of beans with amino acids and trypsin, and of soaking were determined.

2. The original observation of Everson \& Heckert (1944) that raw navy beans were 'toxic' to rats and that autoclaving the beans at $12 \mathrm{I}^{\circ}$ for 5 min destroyed the toxic effect has been confirmed. Longer heating periods were detrimental.

3. Autoclaving also destroyed the trypsin inhibitor and haemagglutinin present in the beans.

4. Raw beans did not support the growth of rats even when supplemented with all the amino acids in which the diet was believed deficient.

5. Rats fed on autoclaved beans supplemented with methionine alone or with all these amino acids grew as well as those fed on the casein diet.

6. The growth of rats receiving raw bean diets was not improved by the addition of trypsin supplements. A level of $2 \cdot 0 \%$ and especially a level of $3.0 \%$ of a trypsin powder was 'toxic' to the rats fed on an autoclaved bean diet.

7. Soaking before autoclaving did not improve the growth-promoting effect of navy beans.

8. The low nutritive value of navy beans appears to be due to a methionine deficiency and the presence of a heat-labile 'toxic' factor(s).

\section{REFERENCES}

Almquist, H. J. \& Merritt, J. B. (r953). Proc. Soc. exp. Biol., N.Y., 83, 269.

Association of Official Agricultural Chemists (1950). Official Methods of Analysis, 7th ed,, p. I3.

Washington, DC: Association of Official Agricultural Chemists.

Bandemer, S. L. \& Evans, R. J. (1963). F. agric. Fd Chem. II, I34.

Borchers, R. (1958). Y. Nutr.66, 229.

Borchers, R. \& Ackerson, C. W. (r95 I). Proc. Soc. exp. Biol., N.Y., 78, 8 I.

Bowman, D. E. (1944). Proc. Soc. exp. Biol., N.Y., 57, г 39.

Brambila, S., Nesheim, M. C. \& Hill, F. W. (196I). F. Nutr. 75, 13.

Evans, R. J. \& Butts, H. A. (1949). Science, ro9, 569.

Everson, G. \& Heckert, A. (1944). F. Amer. diet. Ass. 20, 8r.

FAO (1957). F.A.O. nutr. Stud. no. I6.

Hegsted, D. M., Mills, R. C., Elvehjem, C. A. \& Hart, E. B. (194I). 7. biol. Chem. r38, 459.

Honavar, P. M., Shih, C. \& Liener, I. E. (1962). F. Nutr. 77, Iog. 
Jaffé, W. C. (1949). Proc. Soc. exp. Biol., N.Y., 7I, 398.

Johns, C. O. \& Finks, A. J. (I920). J. biol. Chem. 4I, 379.

Kakade, M. L. \& Evans, R. J. (1963a). Fed. Proc. 22, 55 I.

Kakade, M. L. \& Evans, R. J. (1963b). Quart. Bull. Mich. agric. Exp. Sta. 46, 87.

Kakade, M. L. \& Evans, R. J. (1964). Proc. Soc. exp. Biol., N.Y., I15, 890.

Kunitz, M. J. (1946-7a). F. gen. Physiol. 30, 291.

Kunitz, M. J. (1946-7b). F. gen. Physiol. 30, 3 I r.

Liener, I. E. (1953). F. Nutr. 49, 609.

Liener, I. E. (1958). In Processed Plant Protein Foodstuffs, p. 79. [A. M. Altschul, editor.] New York: Academic Press Inc.

Liener, I. E. (1962). Amer. F. clin. Nutr. II, 28 I.

Rigas, D. A. \& Osgood, E. E. (1955). F. biol. Chem. 212, 607.

Rose, W. C. (1937). Science, 86, 298. 